\title{
No more hot air
}

\section{European heads of state gathered in Brussels today must show they are serious about climate change.}

W hen the European Union's 27 heads of state meet today, they are expected to endorse an energy policy for the continent whose implementation will provide the ultimate test of Europe's ability to meet the challenge of climate change.

European leaders such as Tony Blair and Angela Merkel have talked a good game on the climate-change issue for many years. But Europe's actions to confront stubborn, continued growth in greenhouse-gas emissions have been far less impressive. Today's rhetoric will doubtless imply that this is about to change. However, it is the actual implementation of the plan, rather than the flourish with which it is presented, that will show whether the European Union (EU) is serious about cutting emissions. Sceptics on both sides of the Atlantic think it isn't - and will be watching closely.

Most Europeans want their elected leaders to rise to the challenge and take effective action. They understand that this will involve difficult lifestyle choices regarding, for example, the size of the cars they drive and the amount of energy they waste at home. People are prepared to make these choices provided there is a sense that the burden is being fairly shared.

The heads of state will today discuss an action plan that was drawn up by the European Commission in January and endorsed at a meeting of EU environment ministers last month. It commits the EU as a whole to mandatory reductions in greenhouse-gas emissions of 20-30\% from 1990 levels by 2020 (see Nature 445, 234-235; 2007).

The plan would stipulate a $20 \%$ reduction in emissions and allow for a more arduous $30 \%$ cut if other developed countries (primarily the United States) agree to take mandatory action to reduce their own emissions. It also incorporates a number of secondary, legally binding targets, such as the generation of $20 \%$ of electricity from renewable sources by 2020 .

Given doubts over the true potential of renewable energy sources and other uncertainties, the mandatory nature of the proposal has faced strenuous opposition. However, voluntary measures have done little to change behaviour over the past two decades, so the EU's leaders must now endorse a package of mandatory measures - if only to back up their own well-worn rhetoric on the importance of the climate-change issue. Such mandatory commitments are clearly needed to provide the incentives that will increase research and investment in clean-energy technologies, energy efficiency and the other steps needed to reverse the growth in emissions.

The national circumstances of the leaders gathered in Brussels are varied. Italy, Spain and Portugal, for example, are failing to meet even the modest targets allocated to them as their share of the EU's commitment under the Kyoto Proto$\mathrm{col}$, as the new-found fashion for airconditioning sends their electricity usage through the roof. These countries, along with the poorer member states in the east, are likely to push for the largest and most intensive energy users - Germany, Britain and France - to bear most of the burden imposed
"Most Europeans want their elected leaders to rise to the challenge and take effective action on climate change." by the energy plan. However, the leaders at the meeting realize how wretched they will all look if no agreement is reached, and can therefore be expected to find one.

The current logjam in international climate diplomacy will only be broken by decisive European leadership on the issue. Anything less will recall the grotesque embarrassment that accompanied EU hesitation in the Balkans in the 1990s, when only US intervention prevented a bloodbath.

The climate crisis is a different type of challenge, but is no less momentous for all that. It provides a timely opportunity for the EU to prove that it is capable of leading the world in an issue of global importance. This will require technological innovation, societal backing, economic adaptability and, above all, political will. There is no reason - yet - to conclude that the EU isn't equal to the task.

\section{Tackling tuberculosis}

\section{There is a dangerous gulf between the global} programmes to fight AIDS and TB.

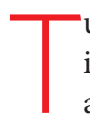
uberculosis (TB) is one of the world's most lethal diseases, and is expected to kill almost 2 million people this year. But it has a relatively low public profile. Worse still, efforts to research, prevent and treat the disease are entangled in an unseemly rivalry with corresponding approaches to AIDS.

TB has been with us for centuries, and has probably already claimed many of the people in the West who are genetically susceptible to it. By far the greatest prevalence today is in Africa and India, where susceptibility to TB often goes hand-in-hand with HIV infection (see Nature Med. 13, 263; 2007 and www.nature.com/news/specials/tb).

Yet the response to the march of the disease in poor countries has been patchy. The World Health Organization (WHO) has led a moderately successful effort to offer basic treatments to as many people as possible, using 40-year-old drugs of limited effectiveness. The US National Institute of Allergy and Infectious Diseases sponsors by far the world's largest TB research programme, and the Bill \& Melinda Gates Foundation is making a determined push to reboot efforts to translate research into clinically useful drugs and vaccines.

However, all this activity is modest in relation to the scale of the problem. TB research programmes are estimated to be worth about \$300 million worldwide - less than one-tenth of the amount devoted to AIDS. Important questions, including how to develop better ways 